\title{
DISCUSSION
}

\section{FOLK COSTUMES DURING THE RITUAL YEAR AND CHANGES IN LIFE, IN A PARISH IN DALECARLIA, SWEDEN: CONTINUITY, VALUES, REVITALISATION}

\author{
Britt Eklund, Katarina Ek-Nilsson
}

\begin{abstract}
In the parish of Boda, like in many other parishes in the county of Dalecarlia, there used to be a kind of dressing that was thoroughly local and homogeneous. This dressing tradition was still alive until far into the 20 th century. We hesitate to call the dressing folk costume as there were no other clothes besides these locally peculiar garments. Everyone followed the same rules of dressing as well as the variations throughout the year (dressing calendar) and in different stages of life. There were hundreds of rules for how to dress on Christmas Day, during Lent, on Easter Day, on a 'normal' Sunday in the summer and in the winter, on Prayer Days - always with differences depending on one's life status: married or not, confirmed or not - and of course on different occasions like weddings and Holy Communion, not to mention everyday and working clothes. It was not possible to break the rules, in which every garment had its own meaning and symbol. This very homogeneous dressing has its demographic, social, and economic explanations. The population was extremely homogeneous, every family being land-owners and nobody poorer or richer than anyone else. In the last decades there has been an increasing interest in old clothing traditions, from before the 20th century. The paper will discuss the nature of this growing interest on the basis of rich archival material and a collection of authentic garments from the 19th century.
\end{abstract}

Keywords: Boda, Dalecarlia, local culture, national garments

\section{INTRODUCTION}

The parish of Boda, like some other parishes in the county of Dalarna (English exonym Dalecarlia), used to have a kind of clothing that was entirely local and homogeneous. Dalecarlia and especially its northern part has, throughout its history, been a province with old and living traditions, as concerns dressing, dialects, music, buildings, working organisations, and other kinds of cultural expressions. 
There are always reasons for such a traditional local culture to arise. During the 18th and 19th centuries, the population living here was homogeneous, consisting of land-owning farmer families. If there were labourers on farms, they were farmers' daughters and sons, waiting to get married and have a farm of their own, so they worked there for just a short period. Due to local traditions of inheritance, all people were equal. The farms were built very closely to each other, in small villages surrounded by fields and forests. The reform concerned with parcelling the fields, which affected most villages in Sweden in the 19th century, never reached this area, which can explain why the farms remained so close to each other. The social community was strong, and so was social control (Erixon 1945: 40).

The farms were not big, but rather of average size. There was a paradoxical old tradition, originating in the Middle Ages, of the so-called herrarbete (migrant labour). This meant that periodically, often every year, men and women would go to the cities, such as Stockholm, Helsinki, or even St. Petersburg, to work in parks, building enterprises, and breweries, but also selling homemade products like wood carvings or ornaments made of hair. We call it a paradox because one would perhaps presume that these migrations might have weakened the local traditions. Instead, the traditions, including the local dress code, were strengthened. People from small villages kept together both at work and leisure. The costume was like a trade mark, since the people from Dalarna were looked upon as reliable and hardworking people. The collective identity was strongly connected to the clothes and the dialect, the apparent signs of "people from Dalarna" (Rosander 1967: 146).

\section{LOCAL DRESSING TRADITION IN DALARNA}

The social and economic homogeneity, negligible social differences, and the migration - constant departing and returning - upheld the traditional way of life, including a homogeneous, but still rich and varying, dressing culture. This dressing tradition was still alive far into the 20th century. We hesitate to call these clothes folk costumes, as there were no other clothes than the locally characteristic garments, i.e. these were not merely 'folk costumes' to be used at special festivals, but clothes that were part of everyday life.

Every parish in northern Dalarna had their own locally distinctive dressing tradition. Everyone followed the same rules of dressing, including the variations throughout the year and due to shifts in life status. We would like to stress that this was not the case in other parts of Sweden but rather quite unique 


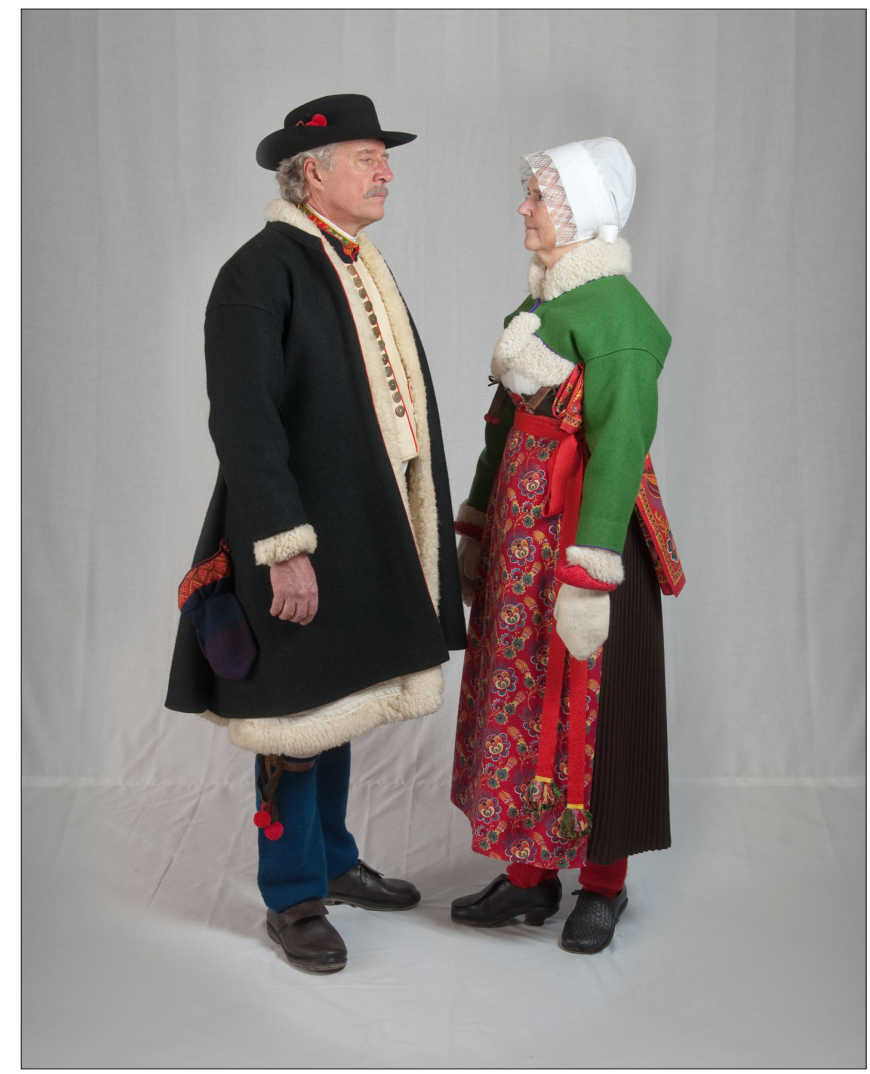

Figure 1. A married couple dressed for church on Christmas Day, one of the most important festivals of the year. The apron is made of imported cloth, probably bought at a fair. The imported textiles were more appreciated than the homemade ones. Photograph by Jon Holmén 2015.

and characteristic of northern Dalarna. There was traditional dressing in other parts of Sweden as well, but never as elaborated as in this region. The set of rules here is called dräktalmanacka (dressing calendar). Along with different garments these rules are very well described in our archives. ${ }^{1}$

The dressing calendar was based on the period of the year, the individual's civil status, and the ecclesiastical year - that is, the calendar of the Lutheran church. This means that the type of dressing follows different church festivals, as well as special occasions like baptism, wedding, and funeral, as well as different kinds of work. The social control over proper dressing was extremely strong. In the records there is, for example, a story of a woman who came to church and found she was wearing an unsuitable apron. As she was not allowed to enter the church dressed that way, she went home, crying bitterly. ${ }^{2}$ 


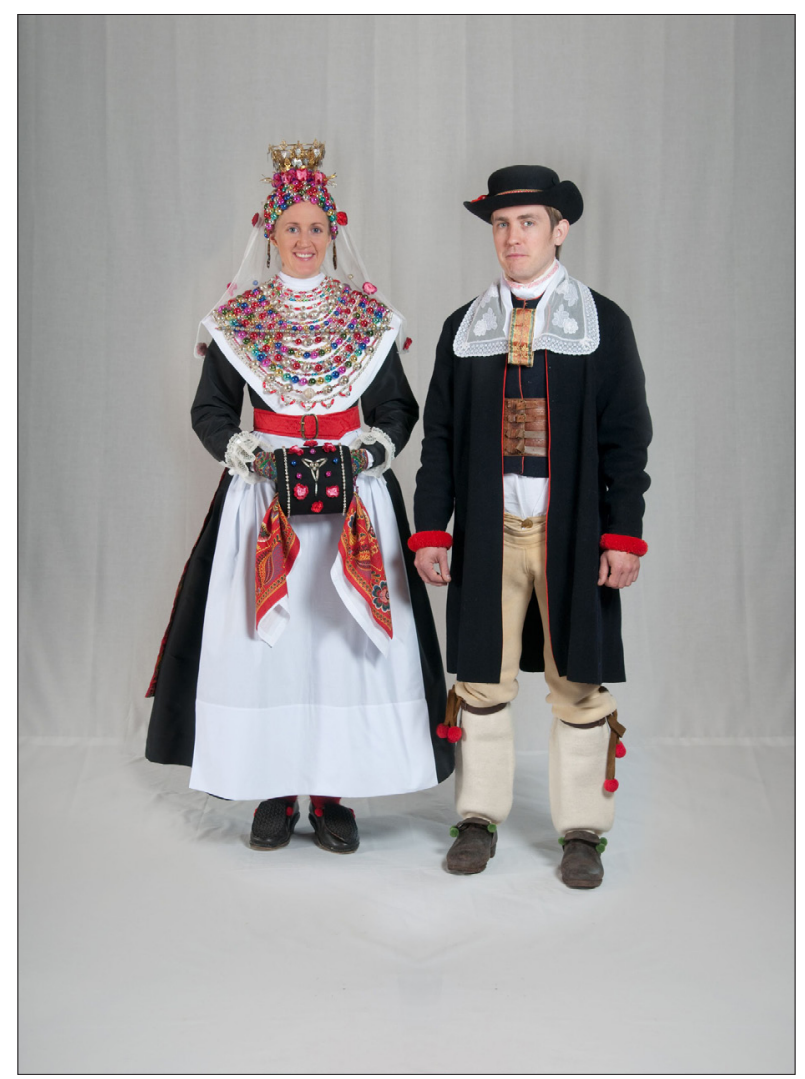

Figure 2. A Crown bride ${ }^{3}$ and her groom. The bride is wearing a white apron (like on the second day of confirmation). A German artist and ethnologist, Kiesewetter, who travelled in Dalarna in 1851, wrote that the brides reminded him of Asian princesses, though the pearls were made of glass and the flowers of paper. ${ }^{4}$ Photograph by Jon Holmén 2015.

There were specific rules of dressing on the first Sunday of Advent, on an ordinary Sunday in wintertime, at Lent, at Whitsun, at Midsummer, on an ordinary Sunday in the summertime, on Judgement Sunday, at Confirmation (the first and the second days), wedding, funeral day, the Sunday after the funeral day, and of course for weekdays and travelling days. ${ }^{5}$

Towards the end of the 19th century the rules began to be dissolved, and around 1900 modern garments were mixed with the traditional costume - which is something very natural as we are talking about a living tradition. 


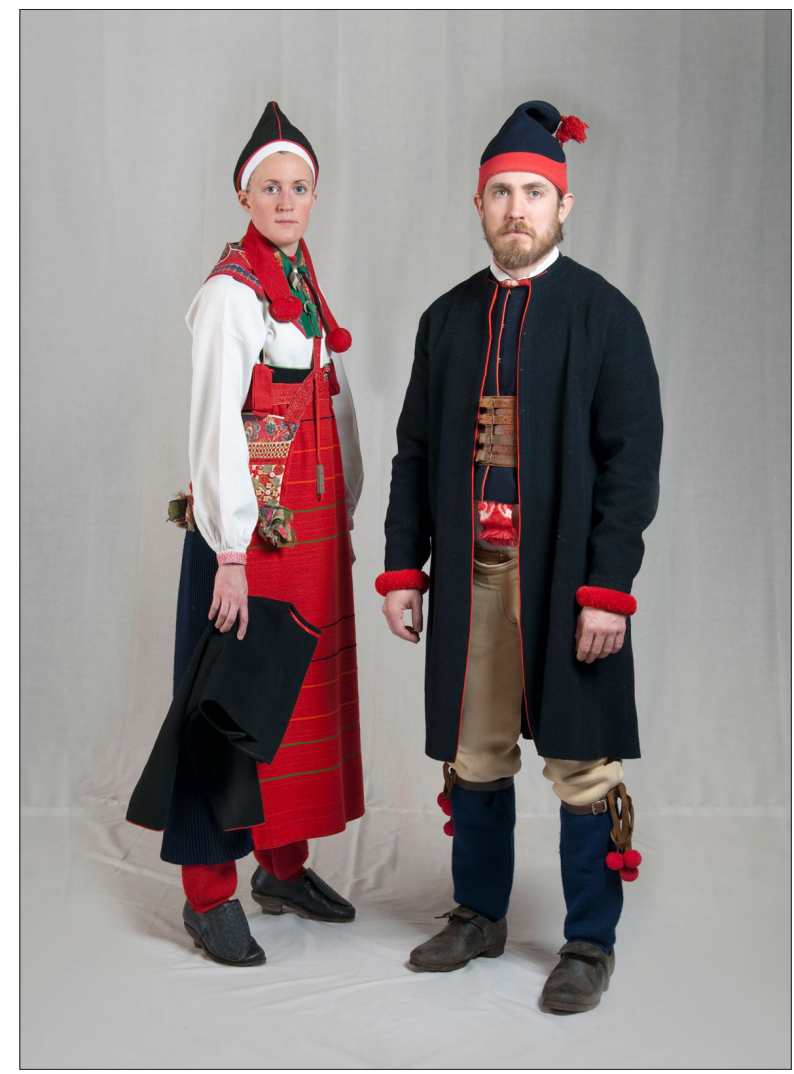

Figure 3. A couple on a Sunday afternoon. The red piece of cloth is not an apron but a gore sewed on the skirt. This is the most common variation used today. Photograph by Jon Holmén 2015.

Today, the traditional dressing is being used at special occasions like confirmation, wedding, Midsummer, family festivals, and official representation. There are many old garments from the 19th century to be found and bought at auctions or on the Internet. The last person who used traditional dressing as part of their everyday life in Boda died as late as 1984.

The traditional and locally characteristic garments were also used on working days. The locals also made alterations in their clothing when they left the farm; for example, on such occasions a woman put on a red apron. ${ }^{6}$ 


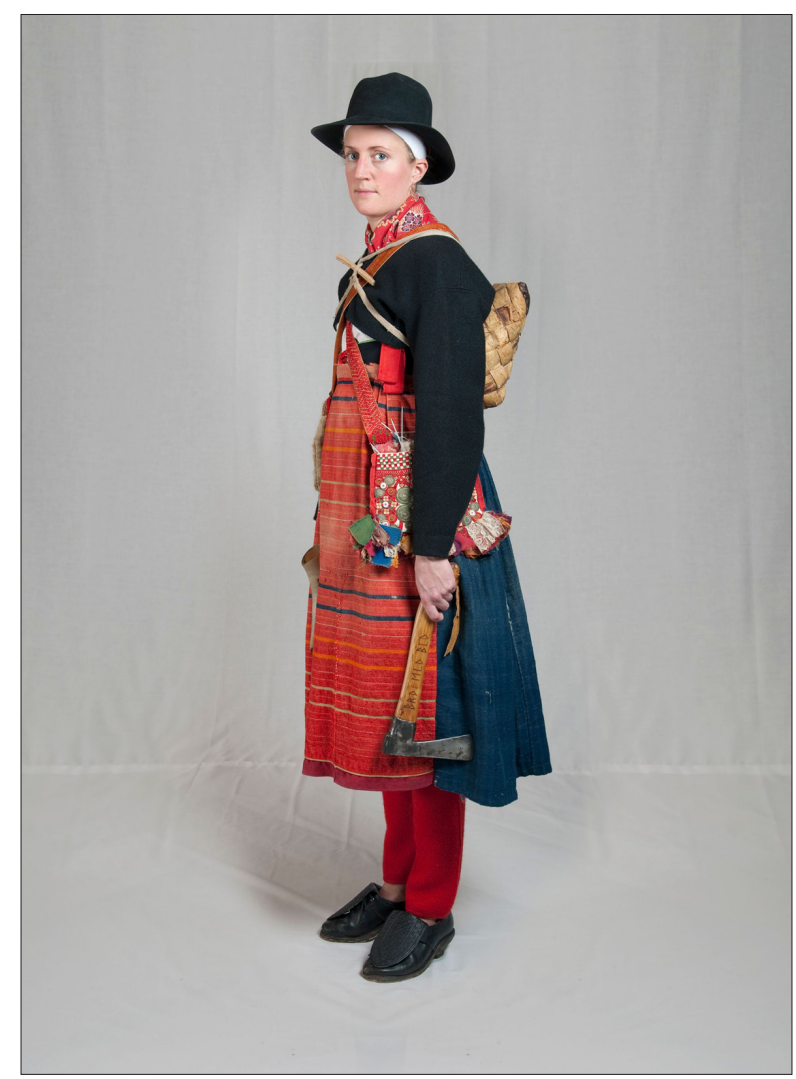

Figure 4. A herding girl in shabby clothes. The axe is used both to clear a path and to chop branches for the cattle. She is carrying a birch bark satchel with some food on her back. A small bag contains flour and salt for the cows, another small bag is for the knitting work. She is carrying a horn to make music and to communicate with other herding girls, for example, to warn them of bears or wolves. She is wearing a man's hat, to frighten the bears and make them think it is a man coming! She has no socks on. Photograph by Jon Holmén 2015.

In the summer it was mainly young women's task to take the cattle to the summer pastures in the mountains to graze, and to take care of them there (Fig. 4). This meant that women had to protect the cattle from wild animals, keep the herd together, milk the animals, and make cheese, butter, and whey cheese. 


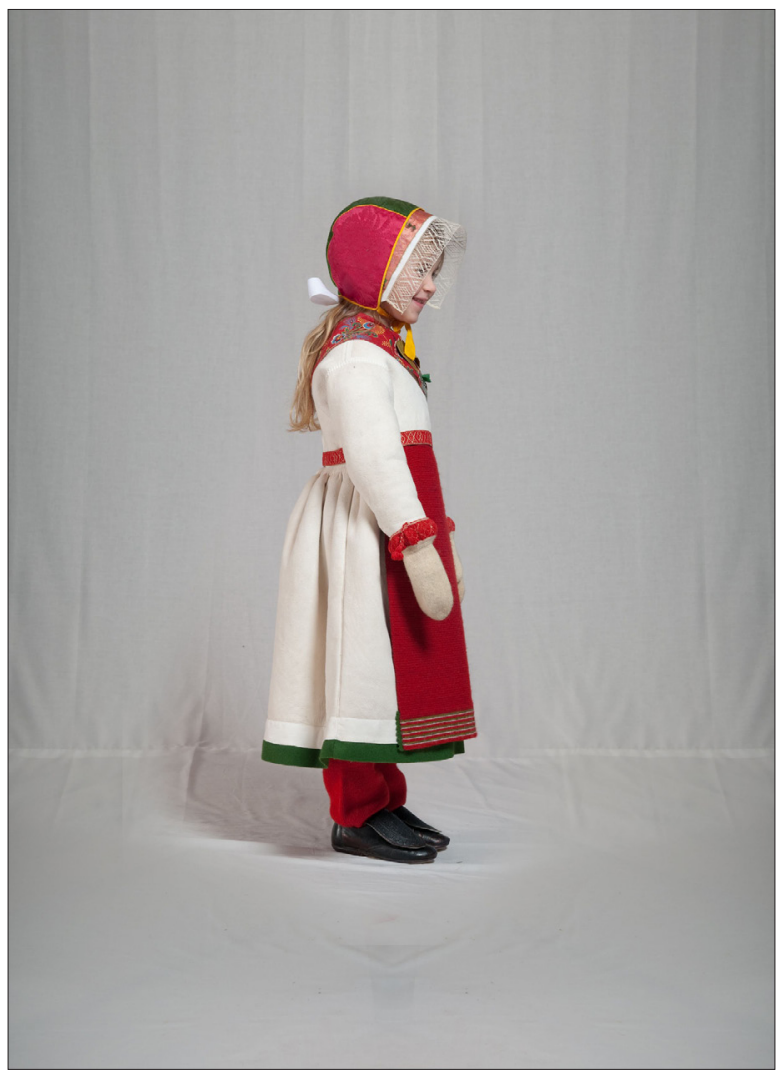

Figure 5. A small girl going to church in the winter. Photograph by Jon Holmén 2015.

The children's costumes were no less traditional than the adults' ones. Both boys and girls wore a frock until they began school at the age of seven. ${ }^{7}$ The only item different in boys' and girls' clothing was their caps. 


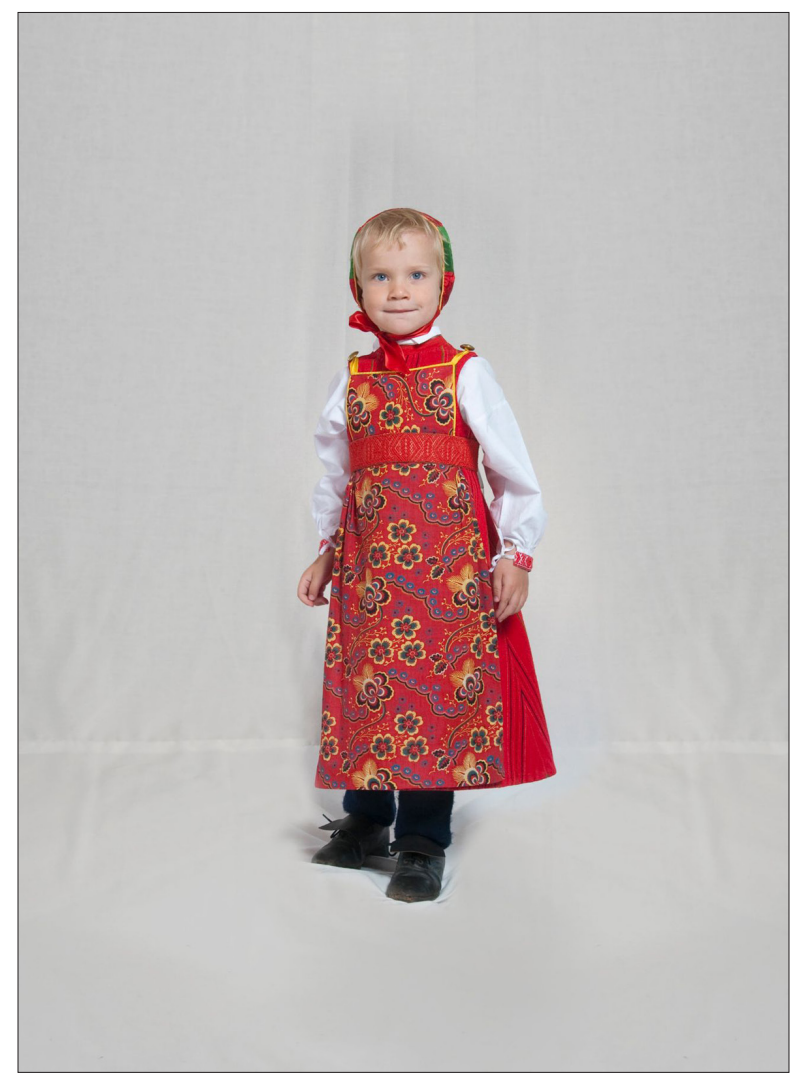

Figure 6. A boy going to church in the summer. Photograph by Jon Holmén 2015.

\section{RENAISSANCE OF FOLK COSTUMES AFTER THE 1970S}

Around 1900, modern garments were mixed with older traditional clothes even in conservative areas such as the parish of Boda. However, in the 1970s a socalled 'green wave' swept over Sweden. Quite many, especially young, people moved from the big cities to the countryside, trying to cultivate their own food and to live as close to nature as they could. Cultural heritage also became more important to many of them, and they started to show a growing interest in folk music and folk costumes. Thus, the green wave gave way to the renaissance of the folk costumes as well as other folk traditions. Many people started to search for their roots, and they bought or made for themselves a folk costume typical 
of the region from which their parents or grandparents originated. A problem could be, however, that many - or even most - parishes or areas in Sweden had never had traditional and locally peculiar clothing like that worn in Boda and the other parishes in northern Dalarna. The northern part of Dalarna is, as stated before, quite unique. Therefore many people simply bought or made a costume that they thought was beautiful.

What was the reason for the growing interest in folk traditions in the seventies? We maintain that one of the many reasons might have been tiredness of modernity, and a very strong reaction against the pollution of the environment. There was also a political discussion about the use of nuclear power in Sweden at the time. Many people were against it, and, on the whole, there was a distrust of engineering and science as symbols of modernity.

In Boda, the young generation in the seventies took into use the older variations of the traditional dressing, that is, the clothing from the 19th century, and not the modernised clothing from the 20th century.

Extensive research has been done to learn more about the 19th century traditions and rules, with a kind of musealisation as a result. In this way the clothing traditions are still kept alive.

\section{NOTES}

1 Andersson, Fräs Erik 1945. ULMA 17600 Kyrkohistoriska arkivets i Lund frågelista 1 rörande kyrklig folksed Boda Dalarna. [The Uppsala Archive of Dialectology 17600, Questionnaire 1 of the Church History Archive in Lund Concerning Folk Religion of the Boda Parish, Dalarna.]

2 Andersson, Fräs Erik 1938. NM E.U. 12061, Boda Dalarna. [The Nordic Museum. Ethnological Archive 12061, Boda, Dalarna.]

3 A Crown bride ('kronbrud') is a bride who is allowed to wear a crown on her head. Only girls who were - or were supposed to be - virgins were considered worthy to wear the crown at the wedding.

4 Ellner, Anna (Grop Anna Olsdotter) 1923. NM E.U. 15534, Dräktskick, Dalarna, Boda socken. [The Nordic Museum. Ethnological Archive 15534, Costume, Dalarna, Boda Parish.]

5 For details see Eklund 2016.

6 Nord, Erik H 1933. ULMA 5567 Frågelista M67 rörande klädedräkt och nakenhet Boda Dalarna. [The Uppsala Archive of Dialectology 5567, Questionnaire M67 on costume and nudity in Boda, Dalarna.]

7 In 1842, compulsory school attendance was inaugurated in all parishes in Sweden. 


\section{REFERENCES}

Eklund, Britt 2016. Dräktalmanacka Boda socken, Dalarna. [Dressing Calendar of the Boda Parish, Dalarna.] Uppsala: Institutet för språk och folkminnen. Available at http://www.sprakochfolkminnen.se/download/18.5a7af053153e51c32cb24 ee/1461082008459/Dra\%CC\%88ktalmanacka+Boda+socken+Dalarna.pdf, last accessed on October 3, 2016.

Erixon, Sigurd 1945. Svenska kulturgränser och kulturprovinser: Kungliga Gustav Adolfs Akademiens småskrifter 1. [Swedish Cultural Borders and Cultural Provinces: The Royal Gustavus Adolphus Academy for Swedish Folk Culture. Small Series 1.] Stockholm: Lantbruksförbundets Tidskrifts AB.

Rosander, Göran 1967. Herrarbete: Dalfolkets säsongsvisa arbetsvandringar i jämförande belysning. [Herrarbete: Seasonal Work in Dalarna, a Comparative Study.] Uppsala: Lundequistska bokhandeln. 